\title{
DOE/EE- -98006398
}

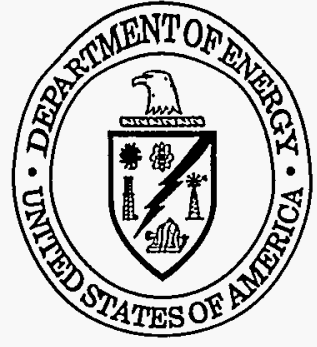

Energy Efficiency and Renewable Energy Federal Energy Management Program

\section{How to Buy Energy-Efficient Residential Windows}

\section{Why Agencies Should Buy Efficient Products}

- Section 161 of the Energy Policy Act of 1992 (EPACT) encourages energy-efficient iederal procurement. Executive Order 12902 and FAR section 23.704 direct agencies to purchase products in the upper $25 \%$ of energy efficiency.

Agencies that use these guidelines to buy efficient products can realize substantial operating cost savings and help prevent pollution.

As the world's largest consumer, the federal govemment can help "pull" the entire U.S. market towards greater energy efficiency, while saving taxpayer dollars.

Efficiency Recommendation ${ }^{a}$
\begin{tabular}{|c|c|c|c|c|}
\hline Climate Zone $^{b}$ & \multicolumn{2}{|c|}{ Recommended } & \multicolumn{2}{c|}{ Best Available } \\
\hline & SHGC & U-factor & SHGC & U-factor \\
\hline Heating & (c) & 0.35 orless & (c) & 0.15 \\
\hline Heating \& Cooling & 0.55 or less & 0.40 orless & $0.20^{c}$ & 0.15 \\
\hline Cooling & 0.40 or less & 0.75 or less & 0.20 & 0.15 \\
\hline
\end{tabular}

a) To receive these thermal performance ratings (SHGC and U-factor), windows must be certified by the National Fenestration Rating Council (NFRC).

b) The map below broadly identifies the relevant climate zones for the U.S.

c) Low SHGCs save cooling energy but increase heating energy. Therefore, lower SHGCs are most important where cooling costs dominate.

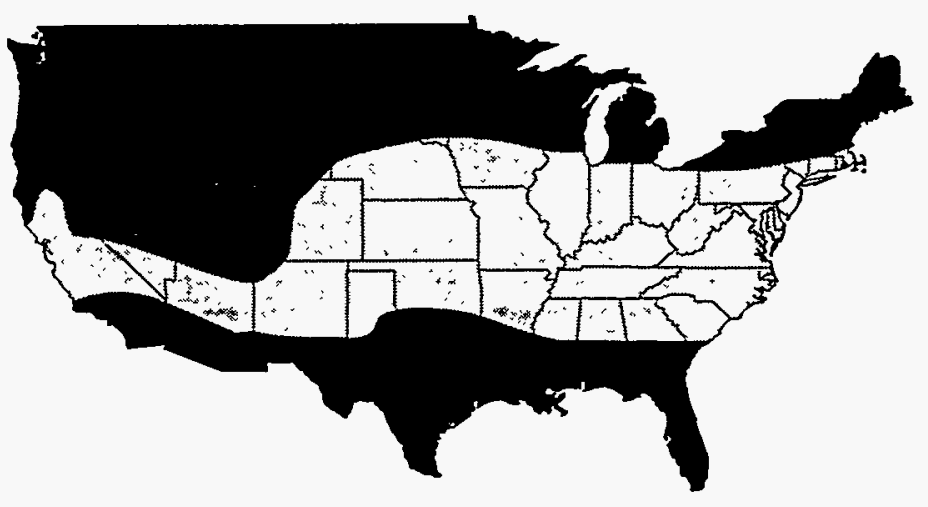

Definitions

SHGC, or Solar Heat Gain Coefficient, is a measure of the solar radiation admitted through a window. SHGC ranges between 0 and $1 ;$ the lower the number, the lower the transmission of solar heat. SHGC has replaced shading coefficient (SC) as the standard indicator of a window's shading ability. SHGC is approximately equal to the $S C$ multiplied by 0.87 .

$U$-factor is a measure of the rate of heat flow through a window. The $U$-factor is the inverse of $R$ value, or resistance, the common measure of insulation.

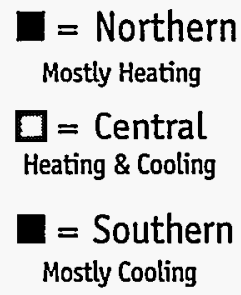
rated SHGC and U-factor values that meet this Efficiency Recommendation for your geographic region. When buying commercially, look for windows with the EPA/DOE ENERGY STAR $^{\circledR}$ label, all of which meet this Recommendation.

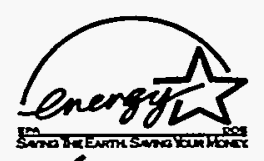

The General Services Administration (GSA) will soon include residential windows in its Federal Supply Schedule 56-IV(A), "Construction and Building Materials."

When contracting for residential windows, specify NFRC-

\section{Where to Find Energy-Efficient Windows}

recommendation

Phone: (202) 484-0880

http://windows.lbl.gov 
Several characteristics of windows affect their efficiency. Features that reduce winter heat loss (lower U-factors) include: insulated glazing units ("IG units"), with two or more panes; "low-e" (low-emittance) coatings, which minimize thermal radiation; lowconductance gas fills (usually argon or krypton); and low thermal conductance spacers and window frames. Weatherstripping in operable windows reduces air leakage (AL), which will soon be rated on NFRC labels (look for AL ratings of 0.30 or below). Energy-efficient windows also minimize occupant discomfort and decrease condensation.

An effective strategy to reduce summer heat gain is the use of windows with low-e coatings, especially spectrally selective low-e coatings, which reduce SHGCs and Ufactors, but not visible light or color. Tinted windows may also reduce solar heat gain, although they transmit less visible light. Visible transmittance (VT) will also be rated on NFRC labels in the future.

To prevent air infiltration when outside temperatures are extreme, keep windows tightly closed and locked; this saves energy as well as preventing drafts. Interior shades and blinds can also help reduce unwanted solar heat gain.

\begin{tabular}{|c|c|c|c|}
\hline Performance & Base Model & Recommended Level & Best Available \\
\hline Window Description & $\begin{array}{l}\text { Double-paned, clear } \\
\text { glass, aluminum } \\
\text { frame }\end{array}$ & $\begin{array}{l}\text { Double-paned, low-e } \\
\text { coating, wood or vinyl } \\
\text { frame }\end{array}$ & $\begin{array}{l}\text { Triple-paned, tinted, two } \\
\text { spectrally selective low-e } \\
\text { coatings, krypton-filled, } \\
\text { wood or vinyl frame }\end{array}$ \\
\hline SHGC & 0.61 & 0.55 & 0.20 \\
\hline$U \cdot$ factor & 0.87 & 0.40 & 0.15 \\
\hline Annual Heating Energy Use & 547 therms & 429 therms & 426 therms \\
\hline Annual Cooling Energy Use & $1,134 \mathrm{kWh}$ & $1,103 \mathrm{kWh}$ & $588 \mathrm{kWh}$ \\
\hline Annual Energy Cost & $\$ 287$ & $\$ 238$ & $\$ 206$ \\
\hline Lifetime Energy Cost & $\$ 4,100$ & $\$ 3,400$ & $\$ 3,000$ \\
\hline Lifetime Energy Cost Savings & & $\$ 700$ & $\$ 1,100$ \\
\hline
\end{tabular}

\section{Cost-Effectiveness Assumptions}

The model shown above is the result of a simulation using a residential windows modeling program called RESFEN. Calculations are based on a prototype house: $1,540 \mathrm{sq}$. $\mathrm{ft}$., two stories, a standard efficiency gas furnace and central air conditioner, and window area covering $15 \%$ of the exterior wall surface area (equally distributed around the house).

\section{Using the Cost-Effectiveness Table}

In the example above, new or replacement windows at the Recommended Level are costeffective if their purchase price does not exceed the price of the Base Model windows by more than $\$ 700$. Similarly, the Best Available windows are cost-effective if their price is no more than $\$ 1,100$ above the price of Base Model windows.

\section{How do I assess the energy savings potential for my situation?}

RESFEN, which is available on the Efficient Windows Collaborative Web site (see "For More Information"), can estimate the heating and cooling costs for many house types, given an approximate knowledge of a few key parameters such as square footage, window area, heating and cooling types, and utility rates. Although the estimated energy costs may not always closely predict actual values, the differences between various window types is generally very accurate.

\section{Buyer Tips}

\section{Usage Tips}

\section{Definition}

Lifetime Energy Cost Savings is the sum of the discounted value of annual energy cost savings, based on average usage and an assumed window life of 25 years. Future energy price trends and a discount rate of $4.1 \%$ are based on federal guidelines (effective from April, 1998 to. March, 1999). The assumed gas and electricity prices are $40 \$ 1$ therm and $6 \$ / \mathrm{kWh}$, the 1996 federal average energy prices in the U.S.
Metric Conversions

1,000 sq. ft. $=93$ sq. meters

1 therm $=100,000 \mathrm{Btu}$

$=29.3 \mathrm{kWh}$

$=105.5 \mathrm{MJ}$

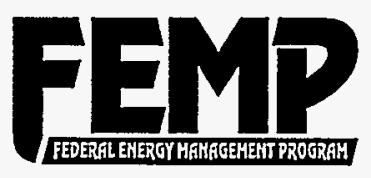




\section{DISCLAIMER}

This report was prepared as an account of work sponsored by an agency of the United States Government. Neither the United States Government nor any agency thereof, nor any of their employees, makes any warranty, express or implied, or assumes any legal liability or responsibility for the accuracy, completeness, or usefulness of any information, apparatus, product, or process disclosed, or represents that its use would not infringe privately owned rights. Reference herein to any specific commercial product, process, or service by trade name, trademark, manufacturer, or otherwise does not necessarily constitute or imply its endorsement, recommendation, or favoring by the United States Government or any agency thereof. The views and opinions of authors expressed herein do not necessarily state or reflect those of the United States Government or any agency thereof. 


\section{DISCLAIMER}

Portions of this document may be illegible in electronic image products. Images are produced from the best available original document. 